\title{
SOLAR-BASED BOOST DIFFERENTIAL SINGLE PHASE INVERTER
}

\author{
C. U. Eya ${ }^{1,{ }^{*}}$ and M. U. Agu ${ }^{2}$ \\ 1,2 DePARTMENT OF ELECTRICAL ENGINEERING, UNIVERSITY OF NIGERIA, NSUKKA. NIGERIA \\ E-mail addresses:1ecandidus@yahoo.com,2 marcel.agu@unn.edu.ng
}

\begin{abstract}
This paper depicts about a power conversion circuit of a Pulse-width modulated (PMW) voltage source inverter known as a Solar-based boost differential single phase inverter. The total harmonic distortion of 67.12\% found in an open loop Solar-based boost differential inverter is reduced down to $22.37 \%$ in closed loop system with the aid of Proportional -integral-Differential (PID) voltage controller. The transient stage of the proposed system takes conical shape before it reaches its steady state. The core characteristics of this type of inverter are: it engenders an ac output voltage that is greater than the dc voltage which is not obtained in conventional inverter, it trims down the many stages of power conversions found in other boost converters to one stage, it mitigates the ripple contents of the input voltage and current concurrently and finally, it is portable. This research also shows the disparity between the simulated results of open loop and closed loop of boost differential inverter systems. The dc power source is photovoltaic cell. The maximum power point tracker is in-cooperated in capturing the maximum power from the sun. The proposed topic has its applications in homes, offices and more in industries
\end{abstract}

Keywords: Photovoltaic, Maximum power point tracker, Boost differential inverter, PID Voltage Controller

\section{INTRODUCTION}

An inverter is an electrical device that converts dc power to ac power at desired output voltage and frequency [1] .The dc power input to the inverter may be got from an existing power supply or battery or from renewable energy sources [1]. Renewable energy is a non-convectional energy that has diversify applications because of its abundance and pollutionfree in the environment [1-2]. Due to the negative effects of fossil-fuel consumption globally, such as air pollution, green house effect, depletion of the ozone layers, the world is currently changing into $67 \%$ of harvesting of renewable energy for electricity generation due its environmental friendly attributes [2]. This concept has invariably achieved and anchored on the applications of power electronics via power conversion, management of power and energy saving [2]. Some of the power conversion processes in power electronics are in $\mathrm{dc} / \mathrm{dc}$ conversion, $\mathrm{dc} / \mathrm{ac}$ conversion (inversion) , ac/dc conversion (rectification), and ac/ac conversion (cycloconversion) [1]. Then, Photovoltaic (PV) energy is presently one of the most viable and useful global renewable natural energies that is used to power inverter due to its cheapness and non-toxic features. But one of the problems that are prevalent to the PV output is that it has a very small voltage level under certain weather situations. And for this reason it is vital to condition it to work at a particular point along its exponential voltage-current characteristics curve known as maximum power point (MPP). Many methods have been proposed for accurately capturing maximum power from the PV systems [2-10]. The [25] applied perturbation and observation method among maximum power point tracking systems for harvesting the pure peak output direct current (DC) since MPP changes with temperatures, insolation, resistance, partial shading, etc yet the PV output is not maximally obtained and non-ripple free existed. An instinctively attractive method to estimating the minimization of distortion from power output would be to drive a small-signal model by fitting a tangent line to the current-voltage curve at MPP, and subsequently calculating the power reduction from linearized model using joule's first law. However, the main power reduction is absolutely greater than would be estimated by this easy small-signal method [6]. 
In this paper we employed incremental conductance method as already used in [10] for heavily harvesting the maximum power from the solar panel. The advantage of this method is that it accurately locates the maximum power point even under rapidly changing atmospheric conditions and its efficiency of operation is $99.8 \%$ unlike observation and perturbation method. The basic idea in incremental conductance method is that the slope of $P-V$ curve plotted becomes zero at the MPP. And the maximum power point tracker then sends a control signal to the DC-DC boost converter within the inverter system through the processing circuit. This then modulates the operating point of solar modules to adjust the voltage across the solar module voltage and the module current. The power output of solar panel has been so useful applications in many areas such as at home for lighting up bulbs, in uninterruptible power supply, inverters, etc. In convectional voltage source inverter (VSI) of [7], produced non-appreciable output voltage due to the fact that observation and perturbation method were applied in tracking maximum power and incorporated many stages of power conversions. This made the power conversion non-economical, large in volume, weighty, more expensive and reduced efficiency. In many industrial inverter applications, the output power has to be greater than the power input. And one of the reasons is to meet up with the challenges of non-linear load requirements. This problem is what another class of inverter known as boost inverter has come up to redress.

Boost inverter is an inverter whose ac output power is greater than power input. Several boost inverters and their deferent control methods have been previously proposed [8-16]. Sliding mode (SM) controllers are well recognized by their vigor and reliability in controlling boost inverters. Some of the formerly anticipated SM controllers are dependent on hysteretic modulation [8-16]. Meanwhile in [10] where sliding mode was used to control boost inverter, it achieved a little bit steady output results but has some demerits such as complex theory, low variable switching frequencies, lack of an inductance averaged current control and constraints to controller parameter selection. The modulation approach of the SM controllers for triggering power converters can be substituted by pulse-with modulation (PWM) [17-18 In this paper apart from application of PWM [17-19], the proportional-integral-differential (PID) controller is also in-cooperated in the feedback system. This gives it edge over other controllers previously stated on both performance and efficiency.

\section{THE SOLAR-BASED BOOST DIFFERNTIAL INVERTER WITH BATTERY STORAGE}

The solar-based boost differential inverter is made up of two bidirectional transformer-less boost converters that is powered by solar panel. Like fuel cell energy systems, it needs to be regulated and in many applications must be supported through addition of energy storage unit (battery) to achieve high quality supply of power. Besides, for PV array, it is sustained with maximum power point tracker to maximize the power output of the array when such systems are used to power ac loads. In this paper, the proposed topic, the incremental conductance method of MPPT is applied for tracking and capturing maximum power. The circuit diagram of the proposed boost differential inverter is shown in Figure 1.

The proposed system, based on the boost-inverter with a back-up energy storage unit, solves the problems of low and variable output voltage of PV and its dynamics of weather conditions. The battery system is designed mostly especially at night. It utilizes two identical bi-directional boost converters and delivers, in a single-stage performing boosting and inversion functions. This result in high power conversion power efficiency, reduced in size and lower cost in mass production.

Generally, the basic component parts of the boost differential inverter are: $V_{\text {in }}$ is the dc input voltage from solar panel, $\mathrm{L}_{1}$ and $\mathrm{L}_{2}$ are the inductances of power inductors, S1-S4 are the power switches with the internal freewheeling diodes, $\mathrm{C}_{1}$ and $\mathrm{C}_{2}$ are the capacitances of output capacitors, and $\mathrm{R}$ is the load resistance of resistor. The switches S5 and S6 in Figure.1 make up two quadrant chopper. These switches are used in controlling the operation of the storage battery. The S5 is connected in series while S6 is connected in parallel to the battery.

During the day time, the S6 operates in first quadrant in complementary condition with S5 switch for charging the battery, but in the night the reverse operation takes place for supplying energy to the inverter. The two points J J, represent where the output voltage is sensed and sent to the control section as in Figure 7a. 


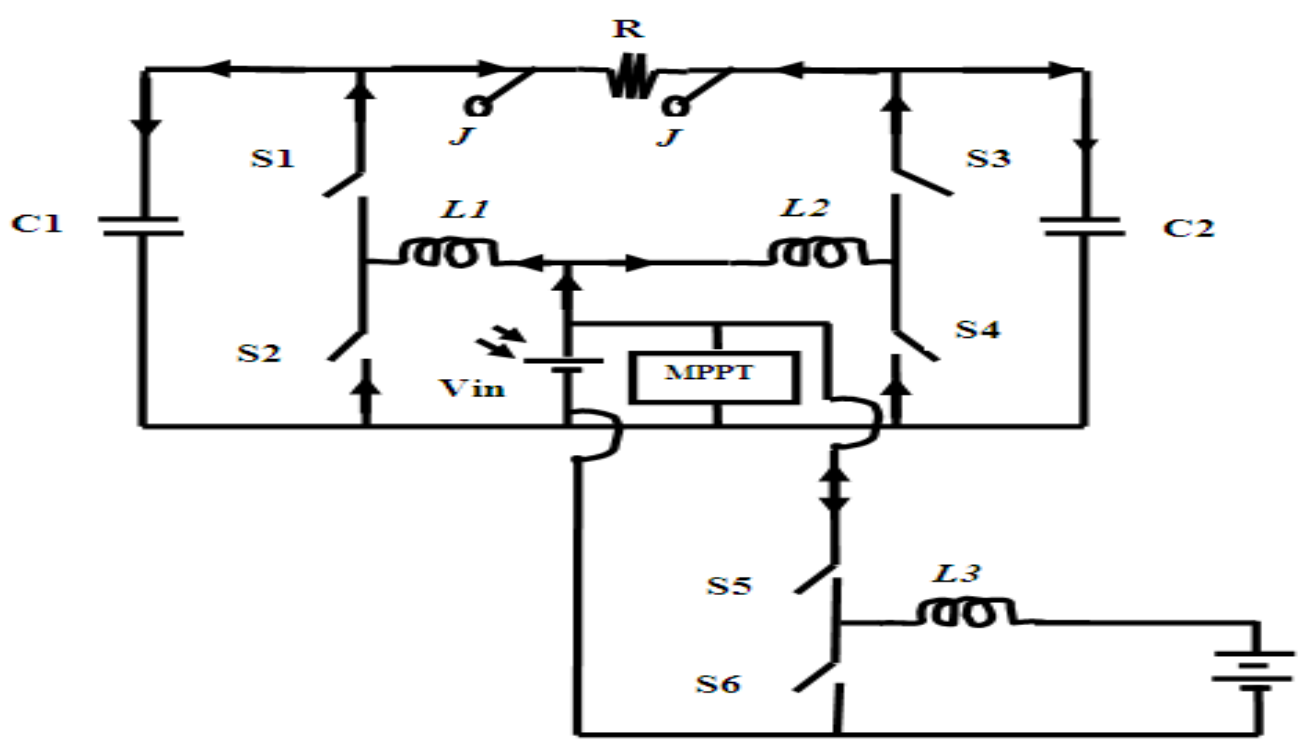

Figure 1. The circuit diagram of the proposed system with storage battery

\section{PHOTOVOLTIAC ENERGY SYSTEM}

Photovoltaic energy systems are made up of arrays of solar cells which create electricity from irradiated light. The yield of photovoltaic system is primarily dependent on the intensity and duration of illumination. PV cell offers clean, emission-less, noisefree energy conversion without involving any active mechanical energy systems. The PV panels are formed by connecting a certain number of solar cells in series and parallel connections. The terminal voltage is built and increased by connecting solar cells in series whereas the terminal current are put up by fixing cells in parallel [4-6].

\subsection{Modeling of Photovoltiac Cell (System)}

It is modeled using a current source in parallel with a diode. The current source of PV cell is directly proportional to the light rays falling on the cell. The circuit diagram of the PV model is shown in Figure 2.

In this paper, a single diode was used with varying ideality quality factor set active at the best I-V characteristics curve match. The circuit diagram is shown in Figure 2. The equation [1-4] that describes the current-voltage relationship of a PV cell is:

$$
I=I_{s h}-I_{0}\left(e^{\frac{q(V+I R s)}{n K T}}-1\right)
$$

In (1), I is the cell current (the same as the module current), $\mathrm{V}$ is the cell voltage which equals [module voltage] $\div$ [number of cells in series], $\mathrm{T}$ is the cell temperature in Kelvin (K), $\mathrm{q}$ is the electronic charge and $\mathrm{n}$ is the ideality factor of diode $[1,2]$.

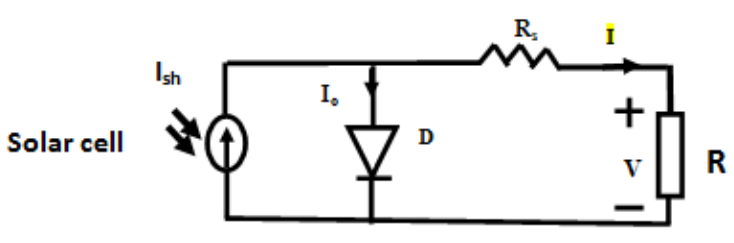

Figure 2: The circuit topology of PV cell

The short-circuit current [1-4] at any given temperature can be deduced as:

$$
I_{s h(T)}=I_{s h\left(T_{r e f}\right)}\left(1+\alpha\left(T-T_{\text {ref }}\right)\right)
$$

$I_{s h(T)}$ is the short-circuit current at a given temperature; $I_{s h(\text { Tref })}$ the short-circuit current given in datasheet measured under insolation of $1000 \mathrm{~W} / \mathrm{m}^{2} \alpha$ is the temperature coefficient of short-circuit current in percent change per degree temperature while $\mathrm{T}_{\text {ref }}$ is the reference temperature of PV cell in Kelvin (K), usually $298 \mathrm{~K}\left(25^{\circ} \mathrm{C}\right)$ and $\mathrm{T}$ is the cell temperature at a given time.

The short-circuit current $\left(\mathrm{I}_{\text {sh }}\right)$ is proportional to the intensity of irradiance, thus Ish at a

given irradiance $(G)$ is [1-4]:

$$
I_{s h(G)}=\frac{G \times I_{s h\left(G_{o}\right)}}{G_{0}}
$$

$\mathrm{I}_{\mathrm{sh}(\mathrm{G})}$ is the short-circuit current at a solar insolation or irradiance, $\mathrm{I}_{\mathrm{sh}\left(\mathrm{G}_{\mathrm{o}}\right)}$ is the short-circuit current measured under insolation of $1000 \mathrm{~W} / \mathrm{m}^{2}, \mathrm{G}$ is the solar insolation at any other given temperature and $\mathrm{G}_{0}$ is the nominal value of irradiance, which is usually $1000 \mathrm{~W} / \mathrm{m}^{2}$.

The reverse saturation current of diode (Io) at the reference temperature $\left(\mathrm{T}_{\mathrm{ref}}\right)$ in addition of diode 
ideality factor at open -circuit condition is expressed as [1-4]:

$$
I_{0}=\frac{I_{s h}}{\left(e^{\frac{q V_{o c}}{n K T}}-1\right)}
$$

In (4) $V_{\text {oc }}$ is the open circuit voltage and $\mathrm{k}$ is the Boltzmann's constant.

The recursive equation used for the output current (I) is calculated iteratively as [1-4]:

$$
I_{n+1}=I_{n}-\frac{I_{s h}-I_{n}-I_{0}\left(e^{q\left(\frac{V+I_{n} \times R_{s}}{n K T}\right)}-1\right)}{-1-I_{0}\left(\frac{q \times R_{S}}{n K T}\right)\left(e^{q\left(\frac{V+I_{n} \times R_{s}}{n K T}\right)}\right)}
$$

The equation (5) is used in simulation of I-V curve characteristics.

\subsection{The Effects of Temperature on the Solar Module Output}

At high temperature of the module especially during the sunny day, the PV module current and voltage decrement as a result of increase in the resistance of the panel. This is because when the temperature rises, the band-gap energy of the intrinsic semiconductor disfigures, and the open voltage decreases following the p-n junction voltage temperature dependency. Then, the I-V distinctiveness under the variation of temperature is shown as shown in Figure 3.

From Figure 3 , it is noticed that the higher the temperature of PV module, the lower the voltage and current which results at the decrease in the power output of the system. For instance, at temperature $\mathrm{T} 1=283 \mathrm{~K}$, the module voltage is about $119.5 \mathrm{~V}$, while at $\mathrm{T} 5=323 \mathrm{~K}$, the module voltage decreases to $109 \mathrm{~V} . H e n c e$, the increase in temperature brings about relatively decrease in power out and efficiency of the module. The graph is obviously sags towards the origin

\subsection{The Effects of Solar Irradiation on the Output of Solar Module}

Solar irradiation is a measure of solar insolation energy received on a given surface area at a given time. When sun illuminates the PV module, some of the rays are absorbed while others reflect. The degree of absorption or reflectivity of the rays wholly depends on the nature of the surface. So the absorbed rays in form of light energy shrink the band gab and thereby allowing the charged carriers to jump from the valence band to conduction band in contribution to the flow of current from the module. As the irradiation of the sun increases on the PV module, the current proportionally increases on the same trend. The I-V characteristic of PV module is shown in Figure 4.

The graph of PV module in Figure 4 above indicates that the greater the sun's irradiation, the more the increase in current and voltage as well as efficient operation of the module. At $\mathrm{G} 1=1 \mathrm{kWh} / \mathrm{m}^{2}$, the current and voltage are $10.50 \mathrm{~A}$ and $119.50 \mathrm{~V}$ whereas at $\mathrm{G} 5=0.2 \mathrm{kWh} / \mathrm{m}^{2}$, they are $2.2 \mathrm{~A}$ and $105.6 \mathrm{~V}$ which conform to the above theory.

\subsection{Maximum Power Point and Maximum Power Point Tracker}

Maximum power point is a special point near the knee of the I-V curve at which the module operates with maximum efficiency and produces maximum power output. A maximum power point tracker (MPPT) is a power electronic DC-DC converter inserted between the PV module and its load to achieve optimum matching of PV impedance and the Load impedance. By using its intelligent algorithm, it ensures the PV module always operates at its maximum power point irrespective of variation of certain factors. The algorithm we used in this proposed system is the incremental conductance method. The advantage of this method is that it accurately locates the maximum power point even under rapidly changing atmospheric conditions.

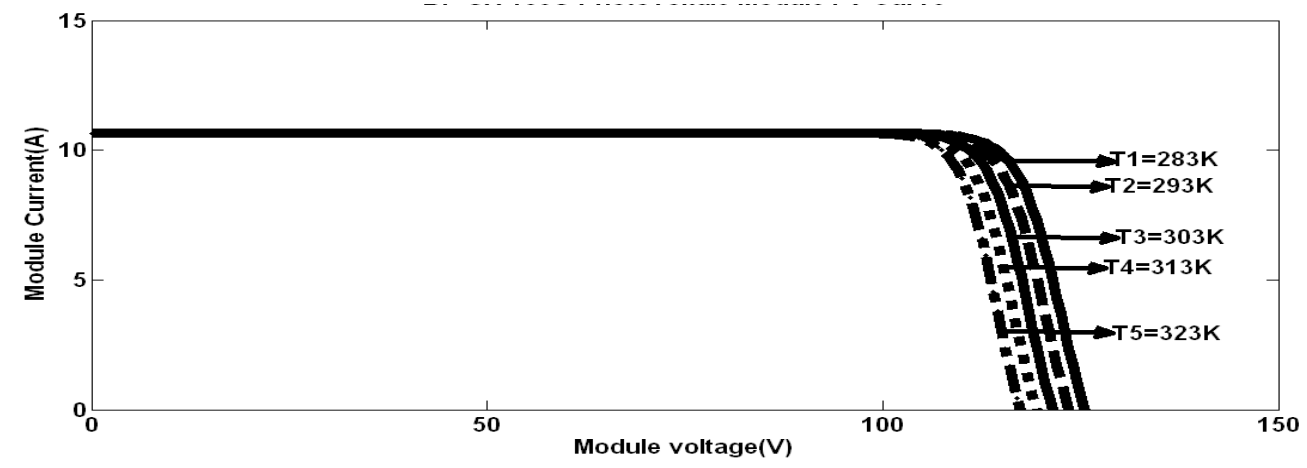

Figure 3: The effect of temperature on the output of solar module 


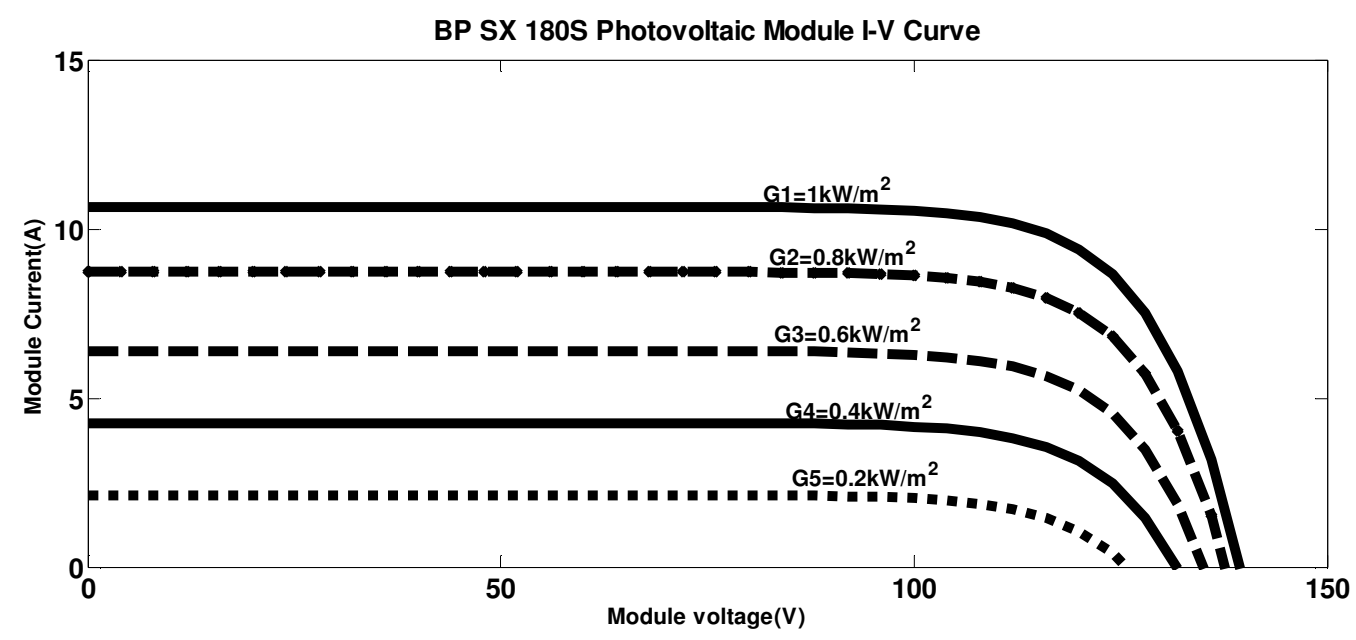

Figure 4: The effect of solar irradiation (insolation) on the output of solar module

\section{ANALYSIS AND SIMULATION OF OPEN LOOP INVERTER AND CLOSED LOOP OF PROPOSED SYSTEM USING PID VOLTAGE CONTROLLER}

In this study, the PID voltage controller is only applied in the closed loop differential inverter. The basic operational principle of this inverter is that as soon as it is powered by the PV array and receives the triggering signals appropriately, each boost converter generates a dc -bias with a deliberate ac output voltage (a dc- biased sinusoidal) wave form as an output, so that each converter generates unipolar voltage greater than the dc source voltage with a variable duty cycle condition as described in equations (6), (7), (10) and (11).

From the Figure $6 \mathrm{a}$, the current ripples mainly flow through S1, C1 and S2 in converter A; and for converter B, they pass through the S3, C2 and S4 according to the arrows. And for this reason, those capacitors enhance absolute filtering of the current ripples that may cause distortions to the output of the inverter while in Figure 5b, the current ripples run through the L1, L2 , S1,S2 and the solar panel . And since the inductor is usually a more lossy device (comprising core loss and a higher conductive loss) as compared to capacitor, and still under no feedback control mechanism, Figure.5b possesses more power losses than Figure 5a which is under PID controller. The basic approach for accomplishing dc to ac conversion with boost attributes is deduced as follows:

$$
\begin{aligned}
& V_{1}=V_{d c}+\frac{A_{0} \sin \theta}{2} \\
& V_{2}=V_{d c}+\frac{A_{0} \sin (\theta-\pi)}{2} \\
& V_{0}=V_{1}-V_{2}=A_{0} \sin \theta
\end{aligned}
$$

$\mathrm{V}_{1}$ and $\mathrm{V}_{2}$ are the output voltages of each boost converters. Ao-peak/amplitude of boost inverter output voltage. Vo is the output voltage. From the equations (6) to (8), it is evident that both boosts are driven by $180^{\circ}$ phase shifted dc-biased sinusoidal references whose differential output is an ac output voltage.

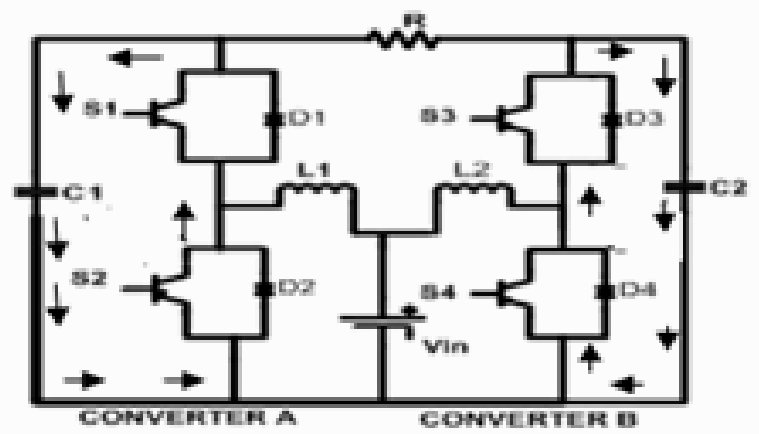

(a)

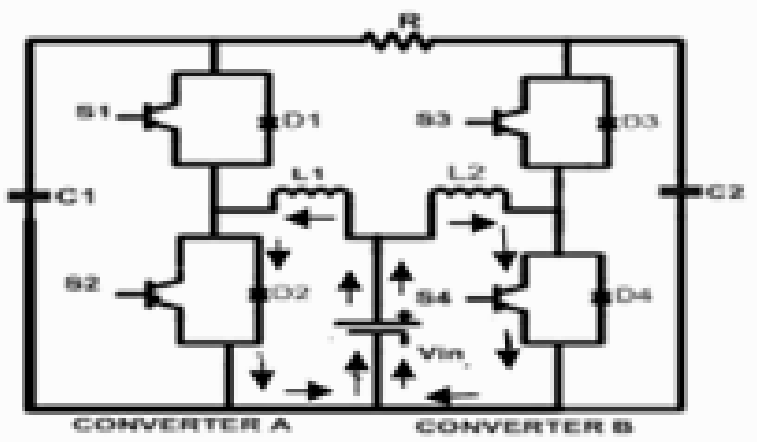

(b)

Figure 5: Flow path of current ripples of boost differential inverter, (a) closed loop, (b) open loop

To increase the efficiency of the converter with variable input voltage the minimum dc-bias $\left(V_{d c}\right)$ for the converters can be determined by: 


$$
V_{d c}>V_{\text {in }}+\frac{A_{0}}{2}+\Delta_{\text {offset }}
$$

In (9), $V_{\text {in }}$ is the input voltage, $\Delta_{\text {offset }}$ is the offset voltage for minimum duty cycle.

Based on the averaging concept for the boost converter, the voltage relationship for the continuous conduction mode (CCM) is given by:

$$
\begin{aligned}
& V_{1}=\frac{V_{\text {in }}}{1-d_{1}} \text { and } V_{2}=\frac{V_{\text {in }}}{1-d_{2}} \\
& \frac{V_{1}}{V_{\text {in }}}=\frac{1}{1-d_{1}} \text { and } \frac{V_{2}}{V_{\text {in }}}=\frac{1}{1-d_{2}}
\end{aligned}
$$

In (10) and (11) $d_{1}$ and $d_{2}$ are the duty cycles of the boost converters.

The working principle of boost differential inverter is summarized using the three circuits in Figures $6 a, 6 b$ and $6 \mathrm{c}$. And they can be analyzed using the equivalent circuit in two modes taken converter $\mathrm{A}$ into deliberation and converter B as a voltage source. This implies that equivalent circuit incorporates one boost converter and the second one is modeled as a voltage source as shown in Figure 6a, hence assuming that the converter operates in a continuous current mode and ideal components are chosen.

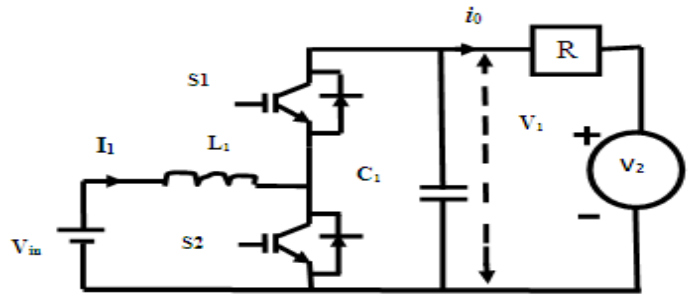

Fig. 6(a): Converter $A$ and voltage source equivalent of converter $B$

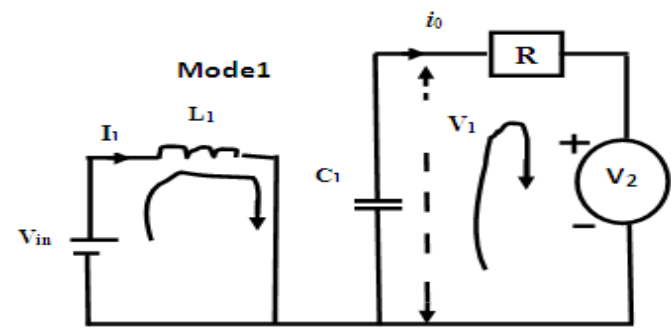

Figure 6(b): Directional current flow at $S_{1}-1$ and $S_{2}=0$.

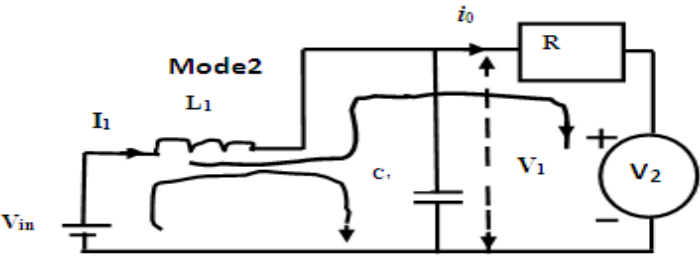

Figure 6(c): Directional current flow at $S_{1}=0$ and $S_{2}=1$.

Furthermore, this operation of the boost differential inverter is studied under two different modes based on the switching conditions. In mode 1 , when $\mathbf{S} 1=\mathbf{0 N}$ and S2 $=$ OFF , the inductor current $\dot{\mathbf{L}}_{\mathbf{1}}$ increases reasonably by building up electrical energy in the inductor and the diode in S2 is reverse biased, then the capacitor $C_{1}$ supplies energy to the load while the voltage V1 decreases as shown in the Figure 6.b. In mode 2, S2=ON and S1=0FF, the inductor current $i_{\mathrm{L} 1}$ flows through $\mathrm{S} 2$, the capacitor $\mathrm{C}_{1}$ and the load. The capacitor, $\mathrm{C}_{1}$ is charged whereas the inductor $\mathrm{L}_{1}$ supplies electrical energy to the capacitor $\mathrm{C}_{1}$ and the load thereby decreasing the current $i_{\mathrm{L} 1}$. The statespace modeling of the equivalent circuit of converter A with the variable $i_{L 1}$ and $V_{1}$ is given by:

$$
\left[\begin{array}{c}
\frac{d i_{L}}{d t} \\
\frac{d V_{1}}{d t}
\end{array}\right]=\left[\begin{array}{cc}
-\frac{R_{a}}{L_{1}} & -\frac{1}{L_{1}} \\
-\frac{1}{C_{1}} & -\frac{-1}{C_{1} R_{0}}
\end{array}\right]\left[\begin{array}{c}
\frac{V_{1}}{L_{1}} \\
-\frac{i_{L_{1}}}{C_{1}}
\end{array}\right] \gamma+\left[\begin{array}{c}
i_{L_{1}} \\
V_{1}
\end{array}\right]\left[\begin{array}{c}
\frac{V_{i n}}{L_{1}} \\
\frac{V_{2}}{C_{1} R_{0}}
\end{array}\right]
$$

$$
\dot{V}_{A}=A_{1} v+B_{1} \gamma+C
$$

Where $\gamma$ is the status of the switches, $\dot{V}_{A}$ and $v$ are the vectors of the state variables $\left(i_{L_{1}}, V_{1}\right)$ and their time derivatives of converter A.

The behaviour of $\gamma$ is expressed as follows [11]:

$$
\gamma\{1 \rightarrow S 1 \text { ON, S2 OFF; } 0 \rightarrow S 1 \text { OFF, S2 ON }\}
$$

\section{THE CONTROL MECHANISM OF CLOSED LOOP OF THE PROPOSED SYSTEM}

It consists of voltage sensor, negative operational amplifier feedback, rectifier, filter, summer, PID controller, comparator, and dead band. The PID controller is a controller where all the three modes of control: Proportional (P), Integral I, and Derivative (D) are combined together. In this controller, there is no offset error and tendency for oscillations is reduced. The control circuit is shown in Figure 7a.

In this work, the operation of the control circuit is described as follow. First, the output voltage of the inverter is sensed using voltage sensor and split into two voltages respectively. This is feedback into bidirectional converters from low-pass filter through six stages realized by only two operational amplifiers of TL084 in converter A and seven stages in converter B. The filtered error voltage is fed into the negative operational amplifier (op amp) of the first stage. This reduces and stabilizes the signal.

In the second stage, the stabilized but reduced voltage signal output of the op amp is rectified and filtered again for better signal quality in the third stage. The summer op amp then amplifies the signals and sends it to proportional-integral- differentiator compensator which appropriately modifies, integrates and differentiates the voltage signals; and then takes them to the comparators where they are compared with the carriers' signals of high switching 
frequencies. The output of the comparator is then moved to the dead band circuits. This dead band circuit ensures that the pulse-width modulated signals are well-gapped to avoid shorting the circuit. For the sake of converter B, a phase shifter in Figure $7 \mathrm{~b}$ is placed between the negative op amp and the rectifier. This phase shifter is what made the converter B seven stages of op amp utilization. It simply turns the sine wave signal from $0^{\circ}$ to $180^{\circ}$ out of phase

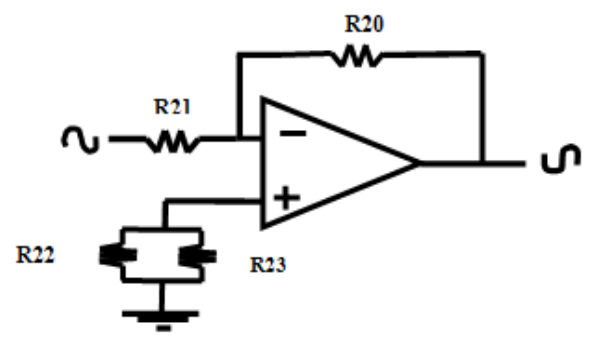

Figure 7b: Phase shifter

And it can be noticed from Figure $7 \mathrm{~b}$. Its pulse width modulated signals are used to fire the switches of S3 and S4, once their voltages are above threshold voltage of the power switches. Through these sequential switching means, the harmonic contents/ripples are drastically mitigated from $67.12 \%$ seen in open loop system to $22.37 \%$ of closed loop proposed system shown in Table 1.

\section{ANALYSIS OF SIMULATION RESULTS}

\subsection{Simulation Results of Open Loop Boost Differential Inverter}

The simulation results of open loop of boost differential inverter were done in Mat lab simulink 2007a environment.

The Figure 8a shows the graphical representation of output voltage of the inverter with respect to time duration of 4 seconds. It is observed that the peak output voltage is at the value of 204.46VAC with ripple signals. These ripple signals negatively affect the performance of the system.

The Figure $8 \mathrm{~b}$ explicitly shows the actual transitory behaviours of the output voltage of the open loop differential inverter under resistive load of 100 ohms. It is detected that it attains 200VAC after 0.10 seconds, but could not stabilize.

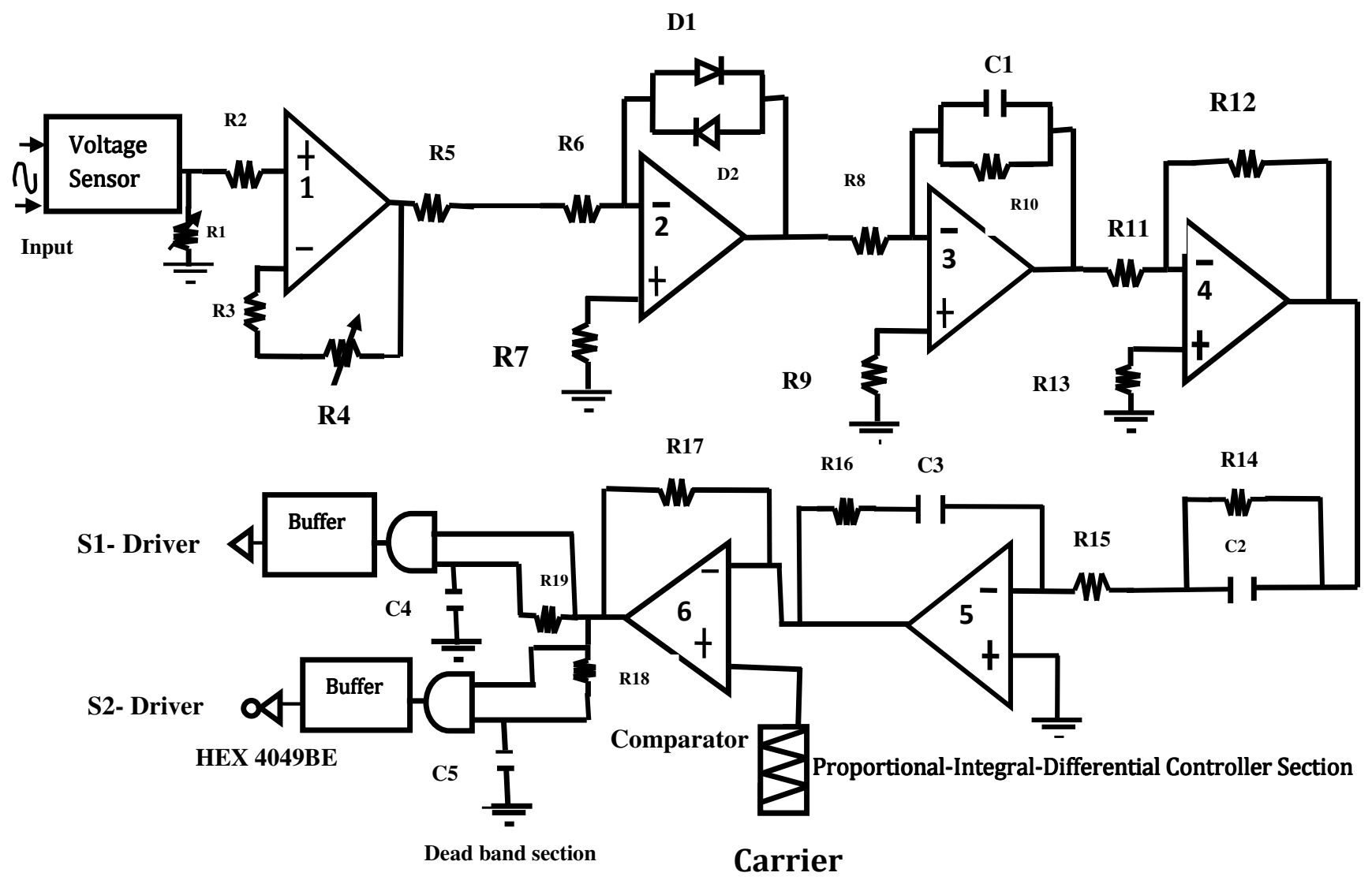

Figure 7a: Outline of control circuit for closed loop of converter A 


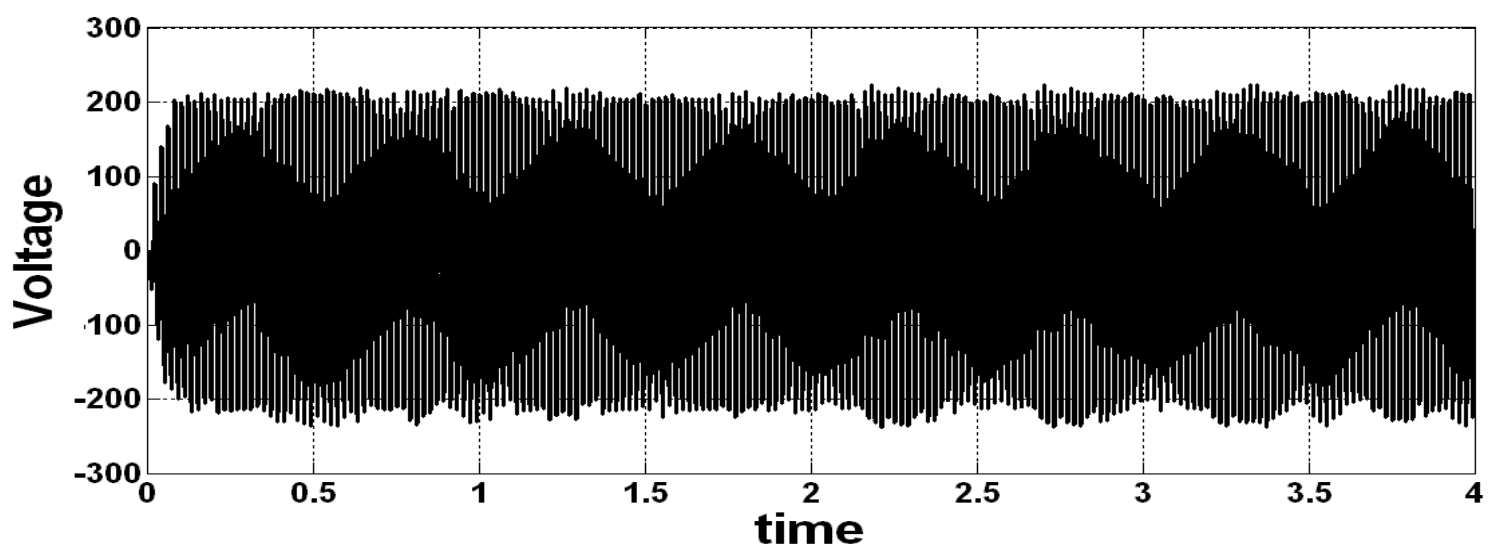

Figure 8a: Voltage waveform of an open loop differential boost inverter

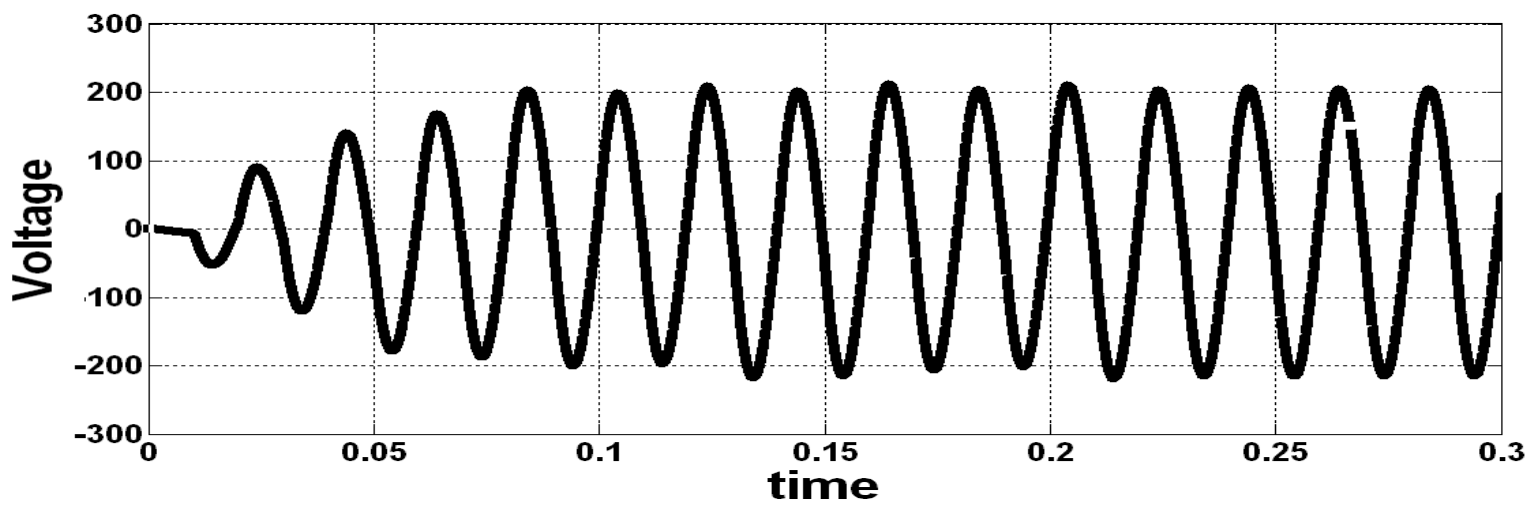

Figure 8b: Transient stage of Voltage waveform of an open loop differential boost inverter

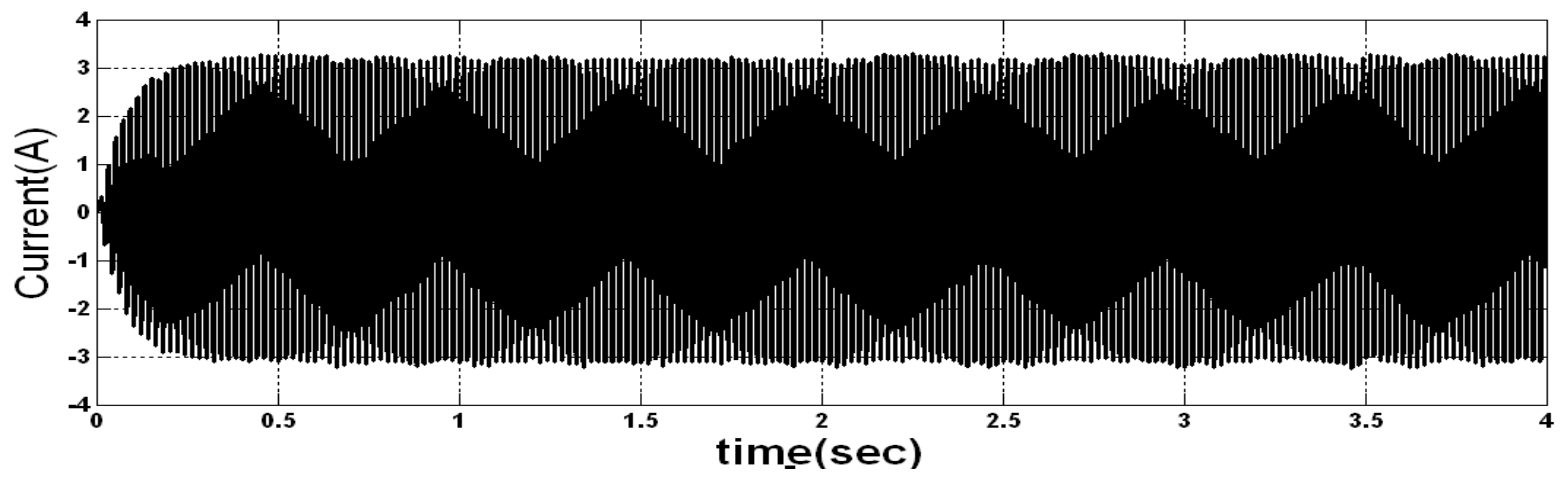

Figure 8c: Current waveform of an open loop differential boost inverter

Fundamental $(50 \mathrm{~Hz})=204.46 \mathrm{~V}, \mathrm{THD}=67.12 \%$

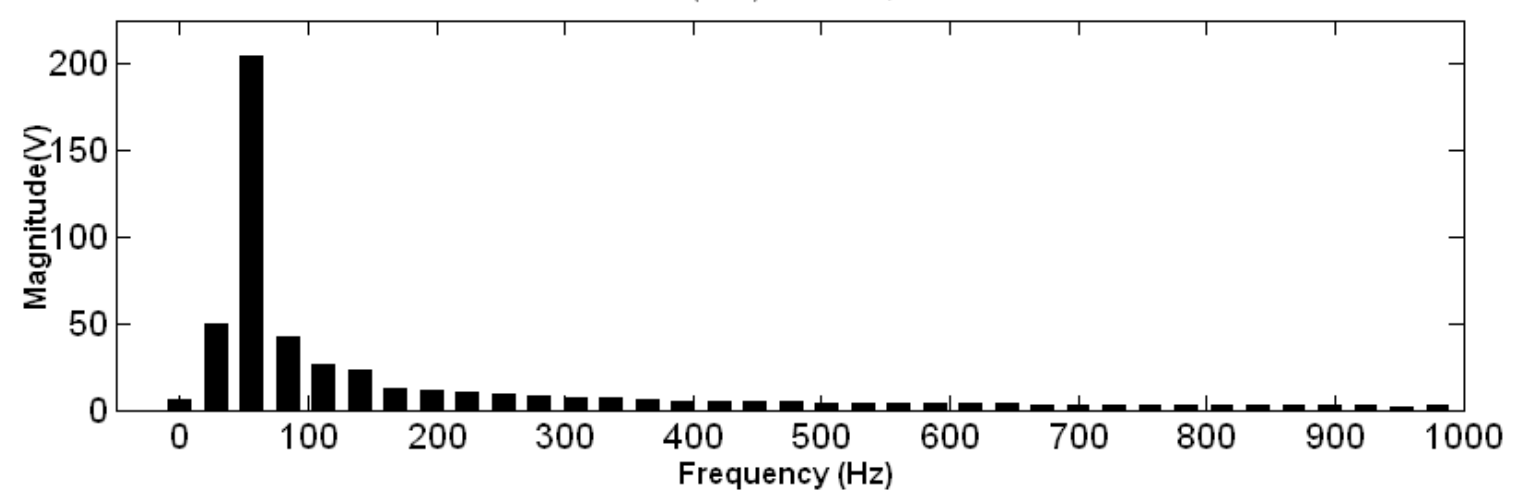

Figure 8d: voltage frequency characteristics under resistive load of open loop differential boost inverter 
Fundamental $(50 \mathrm{~Hz})=204.46 \mathrm{~V}, \mathrm{THD}=67.12 \%$

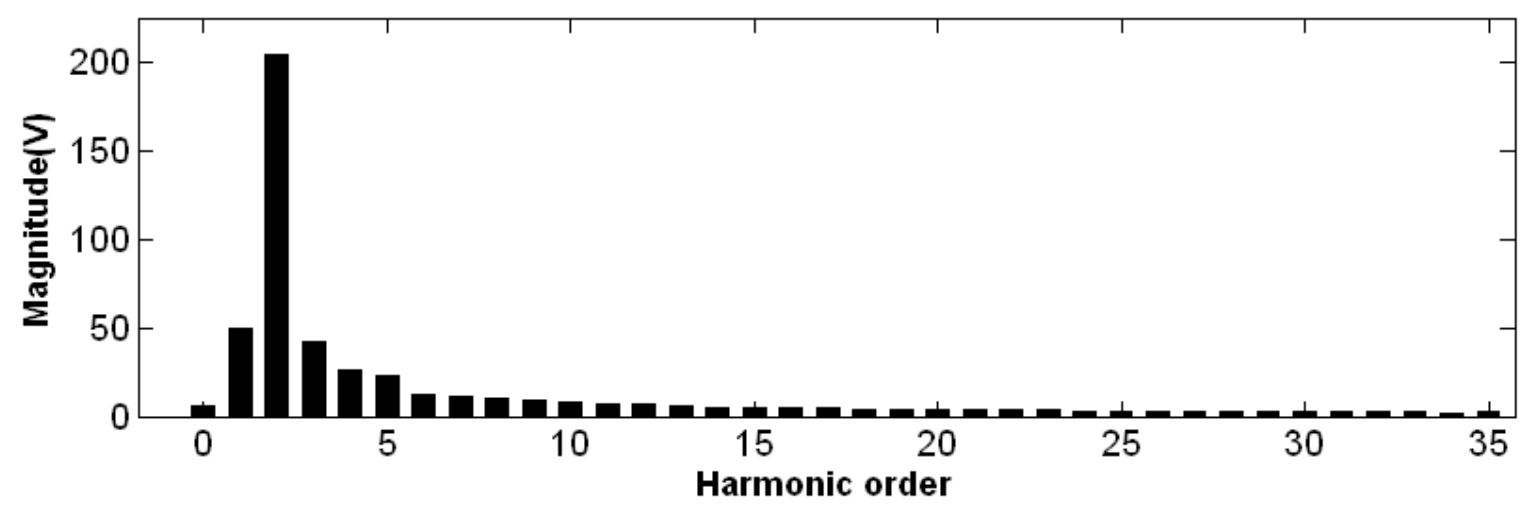

Figure 8e: voltage- harmonic characteristics under resistive load of open loop differential boost inverter

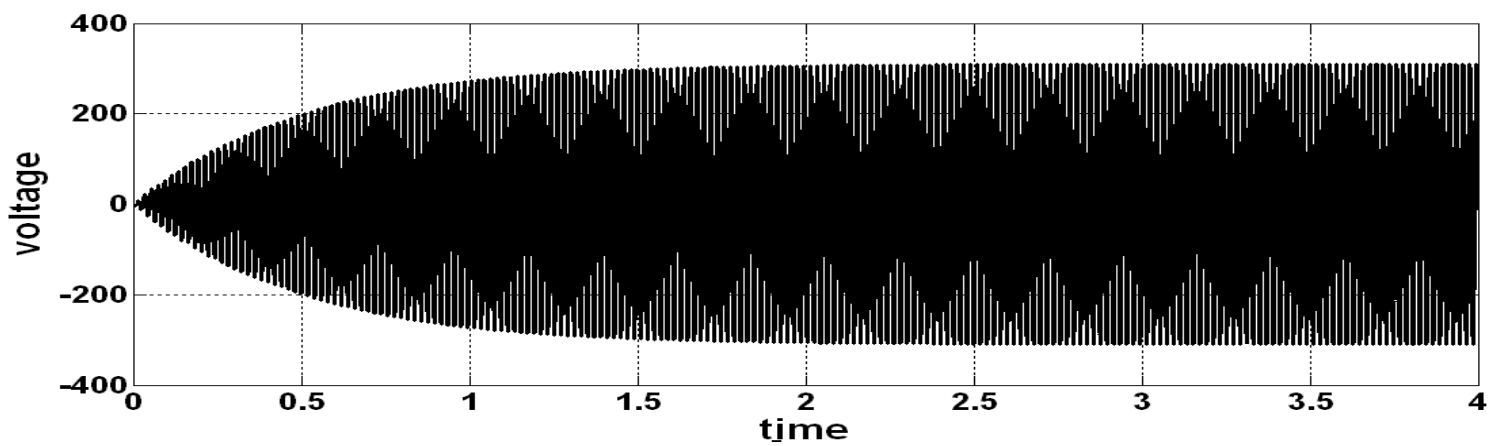

Figure 9a: Voltage waveform of a closed loop differential boost inverter

This is because of conduction losses and harmonic distortions in the system. The current waveform of an open loop boost differential inverter with respect to time is shown at Figure 8c. The current of $3300 \mathrm{~mA}$ $(3.30 \mathrm{~A})$ is observed as the maximum current flowing through the system.

Figures $8 \mathrm{~d}$ and $8 \mathrm{e}$ showed the frequency and harmonic spectra characteristics of the output voltage under resistive load. From them, it is detected that the total harmonic distortion (THD) is $67.12 \%$ at frequency of $50 \mathrm{~Hz}$ and at the voltage amplitude of 204.46V. Moreover, the voltage harmonic order of the open loop boost differential inverter graphically illustrated that there are existence of both dc and ac quantities in the structure. These bring about the poor quality of the waveforms and unavoidably lessen the efficiency of system.

\subsection{Simulation Results of Closed Loop Boost Differential Inverter}

The simulation of the closed loop differential inverters was verified in the simulink within the Math lab 2007a background. And the different stages of waveforms of are shown as in Figure.9

The voltage waveform with reverence to time duration of 4 seconds is shown in Figure 9a. The maximum voltage output as observed in Figure 9a is 312VAC. The most interestly part of the Figure is its growth model. It conically grows from 0.00 second to 2.5 seconds where the stabilization state sets in.

The Figure 9b obviously illustrated the transient stage of the closed loop of the proposed system. There is a gradual increase in the current output of the system until it stabilizes as shown in Figure9c.

For clarity sake, the range of time duration for the steady-state of the closed loop boost differential inverter, shown in Figure $9 \mathrm{c}$ is from 3.75 seconds to 4 seconds. But the actual steady state of the system occurred at 2.5 seconds as can been seen from Figure 9a. At this steady-state region, the total harmonic distortion of the system becomes highly mitigated. It is evident in Figure 9e and 9f.

The Figure 9d shows the waveform of current of the closed loop of the proposed system. The maximum current from Figure $9 \mathrm{~d}$ is $2700 \mathrm{~mA}(2.7 \mathrm{~A})$ and time duration of 2.5 seconds.

The output voltage-frequency spectral characteristics of closed loop boost differential inverter is illustrated in Figure 9e. And it can be noticed that, at fundamental frequency of $50 \mathrm{~Hz}$ and the voltage amplitude of $312 \mathrm{~V}$, the THD is $22.37 \%$. 
The Figure 9f indicates the output voltage-harmonic spectra uniqueness under resistive load of the proposed system. From the graphical representation, it is found out that the THD is $22.37 \%$ at fundamental frequency of $50 \mathrm{~Hz}$ and amplitude voltage of $312 \mathrm{~V}$. Furthermore, the voltage harmonic order of the closed

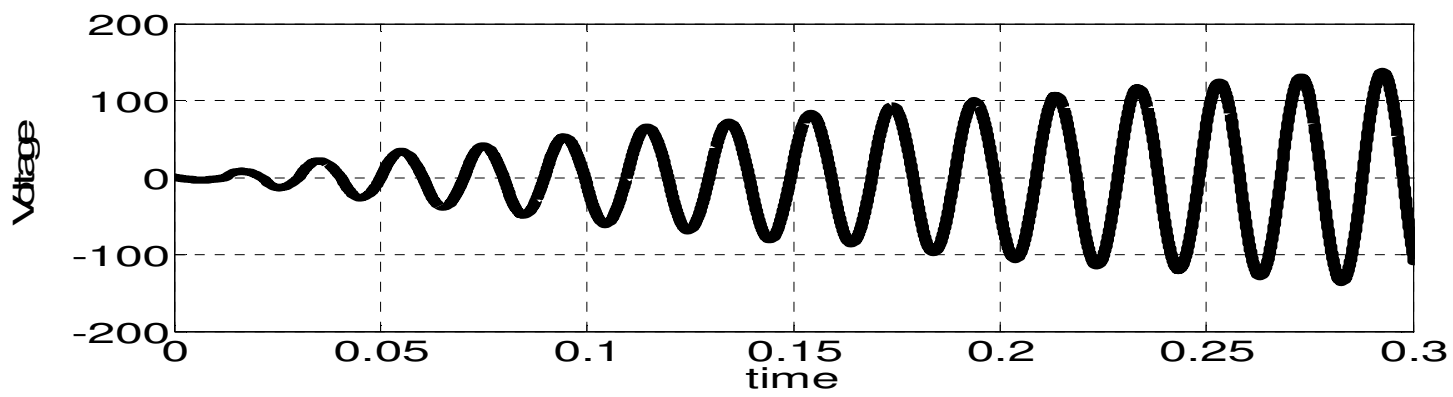

Figure 9b: Transient stage of Voltage waveform of a closed loop boost differential Inverter.

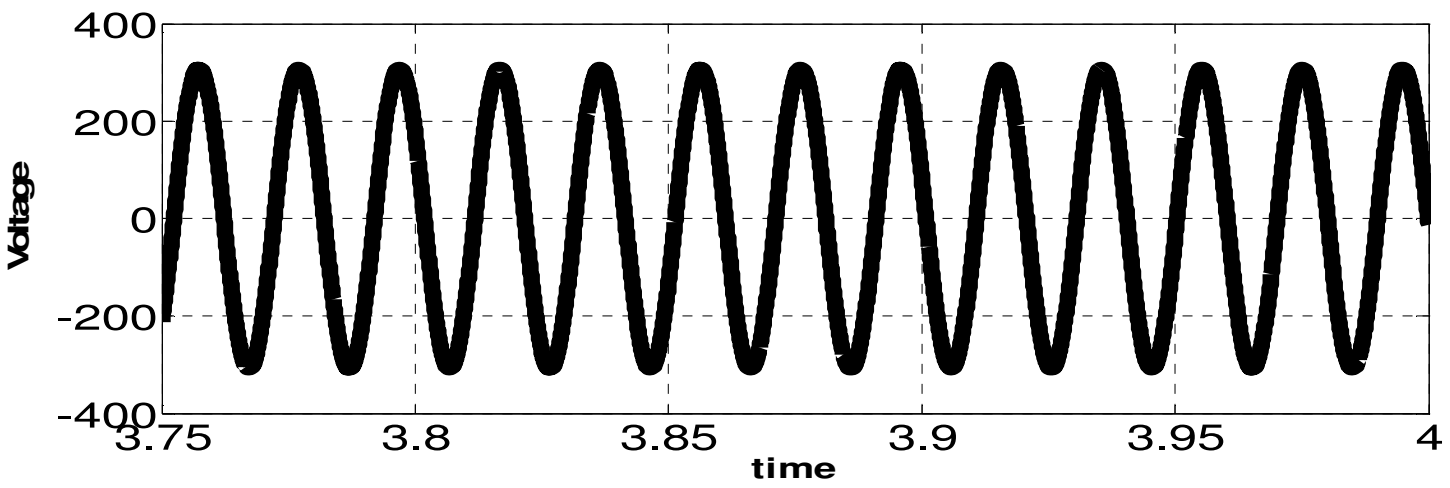

Figure 9c: Steady -state of Voltage waveform of a closed loop boost differential inverter

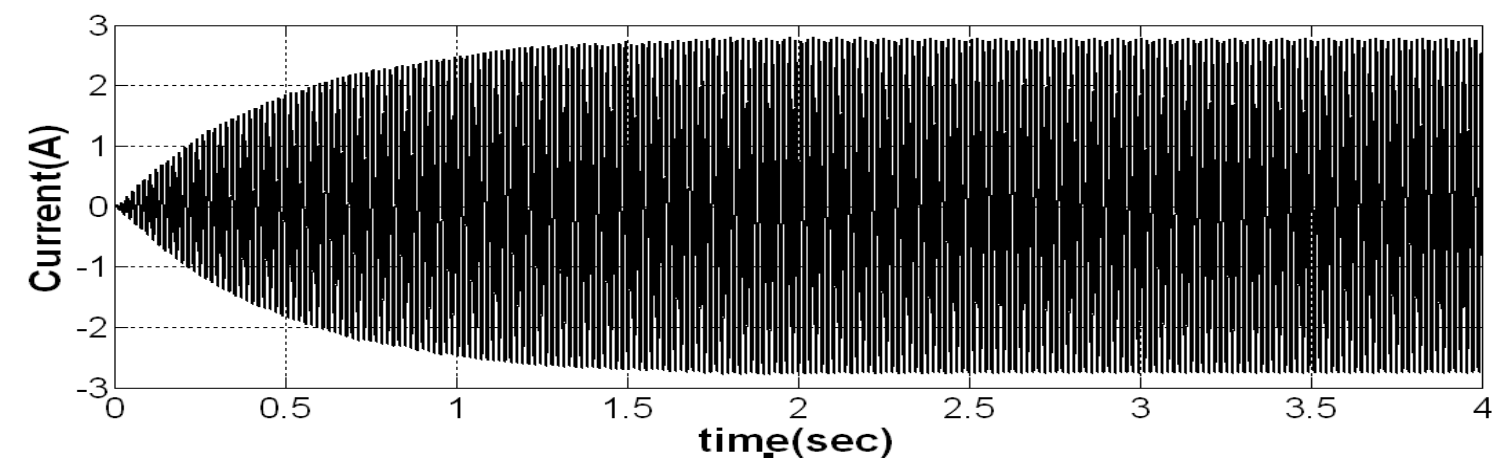

Figure 9d: Current waveform of a closed loop boost differential inverter

Fundamental $(50 \mathrm{~Hz})=312 \mathrm{~V}, \mathrm{THD}=22.37 \%$

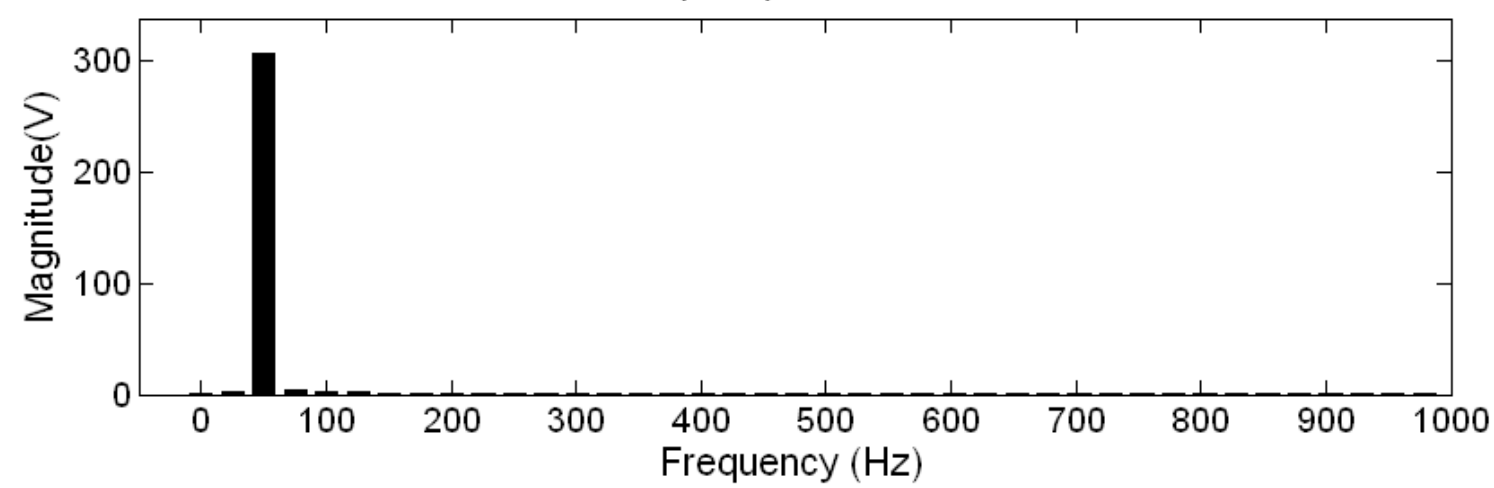

Figure 9e: The output voltage frequency spectral characteristics of closed loop boost differential inverter under resistive load of $100 \mathrm{ohms}$ 


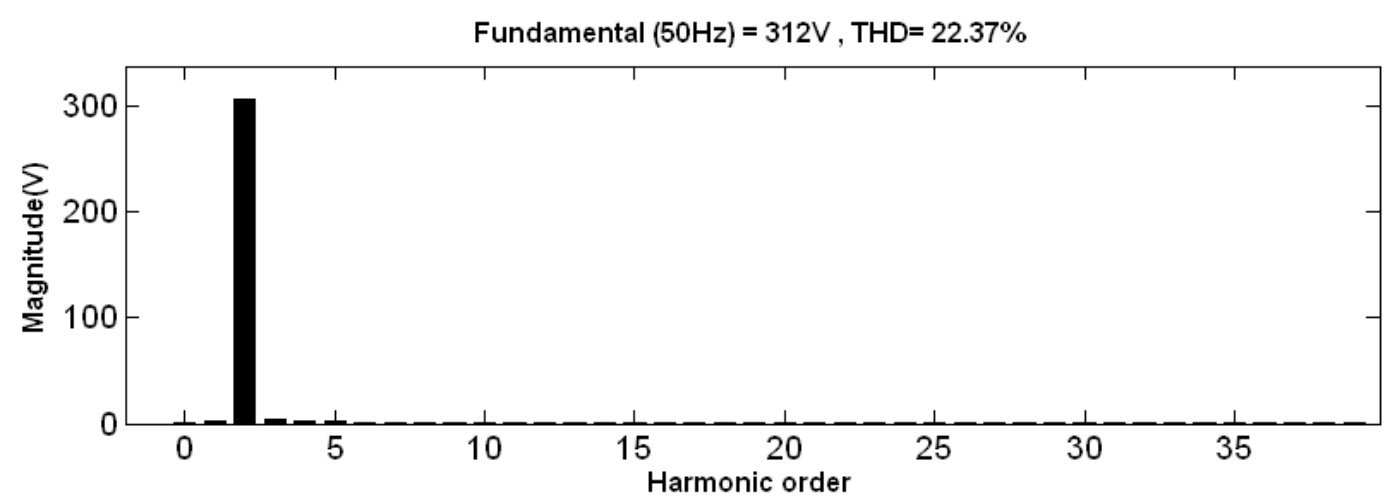

Figure 9f: The output voltage-harmonic spectral characteristics of closed loop boost differential inverter under resistive load of 100 ohms

Table 1: Comparative analysis of open loop and closed loop differential inverters

\begin{tabular}{|c|c|c|}
\hline Type of inverter & $\begin{array}{l}\text { Open loop boost differential } \\
\text { inverter }\end{array}$ & $\begin{array}{l}\text { Closed loop differential boost } \\
\text { Inverter }\end{array}$ \\
\hline Input voltage & 120VDC & 120VDC \\
\hline $\begin{array}{l}\text { Input Current } \\
\text { Switching frequency }\end{array}$ & $\begin{array}{l}\text { 10.50ADC } \\
20 \mathrm{kHz}\end{array}$ & $\begin{array}{l}\text { 10.50ADC } \\
20 \mathrm{kHz}\end{array}$ \\
\hline Maximum AC output voltage & 204.46VAC & $312 \mathrm{VAC}$ \\
\hline Maximum AC output current & $3300 \mathrm{~mA}(3.30 \mathrm{~A})$ & $2700 \mathrm{~mA}(2.7 \mathrm{~A})$ \\
\hline Maximum output power & 674.718watts & 842.40 watts \\
\hline $\mathrm{L} 1=\mathrm{L} 2$ of power circuit & $300 \mu \mathrm{H}$ & $300 \mu \mathrm{H}$ \\
\hline $\mathrm{C} 1=\mathrm{C} 2$ of power circuit & $15 \mu \mathrm{F}$ & $15 \mu \mathrm{F}$ \\
\hline Load resistance & $100 \Omega$ & $100 \Omega$ \\
\hline Kp & - & 10.00 \\
\hline $\mathrm{K}_{i}$ & - & 1.00 \\
\hline $\mathrm{Kd}$ & - & 0.001 \\
\hline R1 to R5 of negative op amp & - & $(20,4.7,10,4.7,20) \mathrm{k} \Omega$ \\
\hline $\begin{array}{l}\text { R6 to } \mathrm{R} 7 \text { of op amp at rectifier } \\
\text { circuit }\end{array}$ & - & $(5.6,5.6) \mathrm{k} \Omega$ \\
\hline $\mathrm{R} 8$ to $\mathrm{R} 13$ & - & $(2.2,10,4.7,10,10,5.6) \mathrm{k} \Omega$ \\
\hline R14 to R23 & - & $\begin{array}{l}(4.7,5,9.7,4.7,20,10,10,10,5,5) \\
\mathrm{k} \Omega\end{array}$ \\
\hline $\begin{array}{l}\text { Total harmonic } \\
\text { distortion(THD) }\end{array}$ & $67.12 \%$ & $22.37 \%$ \\
\hline Power loss & 1089.0W & 729.0W \\
\hline Efficiency & $38.25 \%$ & $53.60 \%$ \\
\hline
\end{tabular}

7. EFFICIENCY OF THE OPEN LOOP SYSTEM AND THE CLOSED SYSTEM OF THE BOOST DIFFERENTIAL INVERTER

Efficiency of an inverter can be defined as power output divided by power input expressed in percent. It varies with ambient temperature, DC input voltage, and under operating power level. It can equally be articulated based on the output power and power losses as follow [1]:

$$
\text { Efficiency }=\frac{\text { output power }}{\text { output power }+ \text { power loss }}
$$

In this research, we considered the maximum power output of inverters and their power losses on the 
resistive loads for the efficiency. They are expressed as follow in equations (14) and (15) [1].

$$
\begin{aligned}
& P_{\text {max }}=I_{\max } V_{\text {max }} \\
& P_{\text {loss }}=I_{\text {max }}^{2} R
\end{aligned}
$$

$P_{\max }$-maximum power output of the inverter, $I_{\max }-$ maximum current output of the inverter, $\mathrm{R}$-load resistance of the resistor. Then, from the graph Figures $8 \mathrm{a}$ and $8 \mathrm{c}$, the maximum voltage and current are $204.46 \mathrm{~V}$ and $3.30 \mathrm{~A}$; and when they are properly substituted in equation (14), the maximum power output of open loop boost inverter becomes 674.718 watts. In addition to this, substituting $100 \Omega$ as shown in table 1 with the maximum output current of $3.30 \mathrm{~A}$ from Figure $8 \mathrm{c}$ in equation (15); produces power loss of 368.64watts of the open loop boost differential inverter. Moreover, when they are plugged into equation (13), the efficiency of the open loop boost differential inverter turns out to be $38.25 \%$. On the other hand, the maximum power output of closed loop boost differential inverter is calculated by substituting maximum voltage and current of $312 \mathrm{~V}$ and $2.70 \mathrm{~A}$ from Figures $9 \mathrm{c}$ and $9 \mathrm{~d}$ into equation 14 appropriately. This gives maximum power output of closed loop inverter of 842.40 watts. In a similar process, the power loss in the resistive of proposed system of 729.0 watts is obtained by surrogating $2.70 \mathrm{~A}$ and $100 \Omega$ into equation 15 . Then, the efficiency of the closed loop boost differential inverter of $53.60 \%$ is got by correctly fitting in the values 842.40 watts and 729.0watts in equation (13).

\section{COMPARATIVE ANALYSIS BETWEEN OPEN LOOP AND CLOSED LOOP BOOST DIFFERENTIAL INVERTERS}

Table 1 shows the similiarities and desparities of utilized parameters as well as the maximum output voltages and currents between the open loop boost differential inverter and the closed loop of the proposed system. It also illustrates that the total harmonic distortion(THD) and power loss of open loop boost differential inverter are $67.12 \%$ and $1089 \mathrm{~W}$ while the proposed system has $22.37 \%$ of THD and power loss of $792 \mathrm{~W}$. Furthermore, the efficiency of the proposed system as shown in the table 1 is $53.60 \%$ whereas $38.25 \%$ is the efficiency of the open loop boost differential inverter.

\section{CONCLUSION}

In this paper, the solar-based boost differential single phase inverter with a PID controlled-feedback mechanism has been presented. A PID control method of the proposed inverter was explicitly discussed. From the Table 1, it is obvious that the closed loop boost differential inverter under the PID voltage controller performs excellently and far better than the open loop differential inverter considering the level of output voltages, maximum output currents, total harmonic distortions, power losses and efficiency. It proffers the merits of simplicity and declined complexity of the circuit. Besides, it is also light in weight, noiseless in operations and can be greatly mass-produced due its lower components cost and simple control method

Hence, this type of inverter has great applications at homes, but more in industrial sectors.

\section{REFERENCES}

[1] Muhammad H.Rashid. Power Electronics Circuits, Devices and application, Third Edition. PrenticeHall of India, 2004.

[2] Sachin Jain and Vivek Agarwal. "A New Algorithm for Rapid Tracking of Approximate Maximum Power Point in Photovoltaic Systems," IEEE Power Electronics Letters, Vol. 2, No. 1, pp. 16-19, Mar., 2004.

[3] Wang Fei, You Shijie, Su Jianhul, Shen Yulang. Research on photovoltaic Grid connected power system and Maximum power point Algorithm in PV Generation," Traction of China electro technical society, No. 5, Vol. 20, May 2005, pp 72-74

[4] T. Esram and P.L chapman. "Comparison of Photovoltaic array maximum power point tracking techniques," IEEE Trans.Energy Converters., vol.22, no.2,pp.439-449, Jun.2007.

[5] V.Salas,E. Olias, A.Barrado,and A. Lazaro. "Review of the maximum power point tracking algorithms for stand-alone photovoltaic systems," Solar energy mater. Solar Cells[online].90(11),pp. 1555-1578. 2011.

[6] S.J Chang.K.T and C.Y Yen, "Residential Photovoltaic energy storage system," IEEE Trans. Ind. Electron, Vol.45.pp.385-3994 June 1998.

[7] V. Vorpe'rian. "Simplified Analysis of PWM converters Using the Model of PWM Switch Part I : Continuous Conduction," Proceeding of the VPEC seminar, Blacksburg,VA, pp 1-9,1989.

[8] Hebertt Sira-Ramirezz. "DC-AC Power conversion on boost converter," International Journal of Robust and Non-linear Control, 2001; 11:589-600

[9] C. U. Eya, C. Odeh, D. B. N Nnadi, M. U Agu, S. E Obe. "Utility Interfaced PWM of Solar fed Voltage Source Inverter Using Fixed-band Hysteresis Current Controller Method," Nigeria Journal of Technology, Vol.31, N0.1, March , 2012, pp.48-57. 
[10] Rafia Akhter,Aminul Hoque. "Analysis of PWM Boost Inverter for solar home application", CISE 2006, International Conference, Enformatika, Volume17,December 2006,ISSN 1305-53,PP212-6

[11] R.C'accres, W.M Garcia, and O. E Camacho. "A buck boost DC-AC converter: Operation, analysis and control," in Proc Int. Power Electron Conf.1998. pp126-131.

[12] R.C'accres and I. Barbi. "A boost dc-ac converter: Analysis, design, experimentation," IEEE Transaction. Power Power Electonics, vol.14,pp.134-141, jan.1999.

[13] R.C'accres and I. Barbi. "A boost dc-ac converter: Operation, Analysis, Control and experimentation," Industrial Electronics, Control and Instrumentation (IECON'95) Nov. 1995, pp.546-551

[14] Nimrod Va'zquez, Carlos Agular, Jaime Arau, Ramo'n O C'accres , Ivo Barbi Jaime Alvarez Gallegos. "A Novel Unterruptible power supply system with active Power Factor Correction" IEEE Transactions on Power Elecronics, vol.17, no.3, May 2002.

[15] P. Malesani, L. Rossetto, G. Spiazzi, and P. Tenti. "Performance optimization of Cuk converter by sliding mode controller for dc-ac Converter Applications", in Proc. Applications Power Electronic conf. (APESC'92), pp. 395-402.

[16] C. I Odeh. "Three -phase Boost DC-AC Converter using sliding mode controller," Nigerian Journal of Technology, Vol.30, N0.1, March, 2011.

[17] Pankaj H Zope, Pravin G.Bhangale,Prashant Sonare. "Design and Implementation of carrier based Sinusiodal PWM Inverter" International journal of Advanced Research in Electrical, Electronics and instrumentation Engineering vol.1 issue 4,0ctober 2012.

[18] Yuen-Haw Chang and Ming-Zong Wu. " High Conversion Ratio Switched-Capacitor Boost DC-AC converter Using Sinusoidal PWM Control," in Proc. International Multi-Conference of Engineers and Computer Scientists (IMECS 2010), Hong Kong,Mar 17-19-2010.

[19] Mohit Bajaj and V.K Dwivedi. "Design and controlling of Proposed Efficient Boost-Inverter Implemented Using Boost DC-DC Converter," International Journal of Advanced Research in Electronics and Communication Engineering Vol.2,Issue May 2013 